\title{
The Standard of Proof in Criminal Proceedings: the Threshold to Prove Guilt under Ethiopian Law
}

\begin{abstract}
The standard of proof plays a vital role in the process of administration of justice. In criminal proceedings, the standard stipulates the degree to which the party who has the burden of proof needs to establish the facts constituting the elements of the crime. This article gives an overview of the meaning and scope of the 'beyond a reasonable doubt' standard and subsequently argues that this standard is adopted in the Ethiopian legal system although it is nowhere clearly stated. It discusses the normative legal framework from which this standard can be inferred. It then explores the practice of the Federal Supreme Court Cassation Division by summarizing and analyzing cases most pertinent to the issue of standard of proof.
\end{abstract}

Hanna Arayaselassie Zemichael *

\section{Key words}

Standard of proof, beyond reasonable doubt, criminal proceedings, Ethiopia

DOI http://dx.doi.org/10.4314/mlr.v8i1.3

"Certainty, absolute certainty, is a satisfaction which on every ground of inquiry we are continually grasping at, but which the inexorable nature of things has placed forever out of reach. Practical certainty, a degree of assurance sufficient for practice, is a blessing, the attainment of which, as often as it lies in our way to attain it, may be sufficient to console us under the want of any such superfluous and unattainable acquisitions".

- Jeremy Bentham **

\section{Introduction}

The standard of proof, along with other basic notions in the law of evidence, plays a vital role in the process of administration of justice. The process of adjudication necessitates the settlement of facts of the case and this is to be ascertained through the introduction of evidence from which the court may draw warranted inferences. While decision-making based on facts is a common

\footnotetext{
* LL.B (AAU), The author can be reached at hmajirans@gmail.com

** Jeremy Bentham (quoted in Terence Anderson, David A. Schum, William Twining (2005), Analysis of Evidence $2^{\text {nd }}$ Ed., (Cambridge: Cambridge University Press), p. 228.
} 
phenomenon in everyday life, the legal system lays down a number of rules governing the decision-making process so as to ensure that the system facilitates correct decisions at least most of the time.

The Ethiopian legal system nowhere clearly states the requisite standard of proof in criminal proceedings. With such a gap in the normative framework, the understanding of this standard is as diverse as the courts themselves resulting in divergent outcomes of cases. This article aims at exploring the meaning and scope of the 'beyond a reasonable doubt standard' and how it found its way into the Ethiopian legal system. It also looks into policy instruments and draft documents to determine the general direction towards which the legal system is headed as far as the standard of proof is concerned. Giving a detailed account of selected decisions of the Cassation Bench of the Federal Supreme Court, the article provides a comprehensive account of the jurisprudence of this Court on the issue.

The first section discusses the meaning of the beyond a reasonable doubt standard drawing from the experience of other countries that apply the same standard. It also explores the effect of affirmative defenses and presumptions on the scope of the standard. After a look at various legislations, the second section then argues that 'beyond a reasonable doubt' is the standard impliedly included in the Ethiopian legal system. The third section provides a brief overview of legal presumptions in Ethiopian criminal law with a view to determine whether and to what extent such presumptions affect the burden and standard of proof in criminal proceedings. The practice of courts in Ethiopia, particularly that of the Federal Supreme Court, Cassation Division is discussed in the fourth section by analyzing selected cases that are most pertinent to the issue. It notes that the practice is divergent and inconsistent with the normative framework.

\section{Beyond a Reasonable Doubt Standard}

This section explores the meaning of the beyond a reasonable doubt standard. It gives an overview of the prevalent formulations of the standard under the US legal system and the criticisms leveled against each after which a discussion of affirmative defenses and presumptions follow.

\subsection{Meaning}

The beyond a reasonable doubt standard was developed from the realization that in human affairs what can be achieved at best is 'moral certainty'- as opposed to 'full certainty' as in mathematics or logic. ${ }^{1}$ When it comes to moral certainty, what is required is not proof beyond all doubt, but rather establishing

${ }^{1}$ Larry Laudan (2006), Truth, Error and Criminal Law: An Essay in Legal Epistemology, (New York: Cambridge University Press), p. 32. 
the fact as firm and settled with the help of the presented evidence and testimony. Among the different theories and formulations surrounding the beyond a reasonable doubt standard, Larry Laudan has identified five formulations, discussed them as the major variations and identified the problems with each. ${ }^{2}$

\section{a) Analogy with important life decisions:}

According to this formulation, beyond a reasonable doubt is compared with important decisions one has to make in everyday life. Laudan criticizes this formulation by pointing out that in almost all important life decisions, people act despite the fact that there are reasonable doubts. ${ }^{3}$ The degree of doubt that is considered acceptable under the beyond a reasonable doubt standard is much lesser than what people entertain in their private decisions no matter how important. Thus equating the beyond a reasonable doubt standard with making important life decisions is erroneous because it would amount to allowing a guilty verdict despite the existence of reasonable doubt.

\section{b) Doubt that would make a prudent person hesitate to act:}

Instead of describing what belief beyond reasonable doubt is, this test attempts to explain what a 'reasonable doubt' is. Accordingly, a reasonable doubt is described as a doubt that would cause a prudent person to hesitate to act on that belief (as opposed to the kind of doubt despite which you would act without hesitation). This analogy can be criticized for the same reason as the first since one may hesitate to act in an important affair not only when there are reasonable grounds. It has also been criticized for being too vague in its formulation. ${ }^{4}$

\section{c) An abiding conviction of guilt:}

This is very similar with the historical 'moral certainty' formulation. The literal meaning of the word 'abiding' envisages that the fact-finder must believe in the

${ }^{2}$ This section of the discussion is based on what is presented by Laudan who outlined the various definitions in his book drawing from the experience of US courts in jury instructions on the standard of proof and the decisions of appellate courts on the issue. For a detailed discussion of each of the definitions see Id, pp. 34-51.

${ }^{3} I d .$, p. 36.

${ }^{4}$ After citing this standard, one judge has written "I was always bemused by its ambiguity. If the jurors encounter a doubt that would cause them to "hesitate to act in a matter of importance," what are they to do then? Should they decline to convict because they have reached a point of hesitation, or should they simply hesitate, then ask themselves whether, in their own private matters, they would resolve the doubt in favor of action, and, if so, continue on to convict?", See, Jon O. Newman (1993), "Beyond "Reasonable Doubt"”, New York University Law Review, Vol. 68, No. 5, p. 4. 
guilt and conviction of the accused and that this belief will last for a considerable period of time. But making such determination prospectively is very difficult, if not impossible. The problem with this definition is that it puts too much emphasis on the subjective belief of the fact-finder instead of laying down objective criteria such as the level of evidence required. This, in turn, may result in conviction being doled out without a high degree of guilt having been established thereby defeating the very purpose of the beyond a reasonable doubt standard.

\section{d) Doubt for which a reason could be given:}

Here the beyond a reasonable doubt standard is explained by requiring that the fact-finder is to find the defendant not guilty if, after considering the evidence, he has a lingering doubt about such guilt for which a reason can be given. By simply requiring 'a reason' (and failing to qualify the degree), this description of the standard has the effect of distorting what it stands for; it fails to incorporate the qualification of the doubt as 'reasonable'.

\section{e) High probability:}

Under this definition, a belief beyond reasonable doubt is considered as one that is highly probable. It is an attempt to quantify the degree of likelihood to be attached to the truth of a belief. The fact-finder is to convict the defendant when he is convinced of the guilt of the defendant close to certainty measured by a numerical degree of confidence. This formulation, though advocated by some legal scholars, ${ }^{5}$ has been expressly rejected by various courts. ${ }^{6}$ An objection leveled against this definition is that it involves an explicit admission that the criminal justice system admits a certain number of wrongful convictions. This in turn, it is argued, will erode public confidence in the whole process. ${ }^{7}$

Proponents of this view thus hold that it is better for us to refrain from expressly admitting the possibility of wrongful convictions although it is impossible to set up a perfect system of criminal procedure that avoids all errors. Another problem with attaching mathematical probability to the standard is that there is no agreement as to where it is to be set. The first attempt to quantify beyond a reasonable doubt was made in 1970 where, after a research, it was concluded that the standard stood between a 0.70 and 0.74 probability. Others

\footnotetext{
${ }^{5}$ One writer, for example, stated “... the criminal beyond-a-reasonable-doubt standard is akin to a probability greater than 0.90 or 0.95 . Perhaps, as most courts have ruled, the prosecution is not allowed to quantify "reasonable doubt," but that is only an odd quirk of the math-phobic legal system" (Edward K. Cheng (2012), "Reconceptualizing the Burden of Proof", 122 Yale Law Journal (2012) Working Draft of June 18, 2012), p. 1.

${ }^{6}$ See, for example, McCulloch v. State, 99 Nev. 72, (1983).

${ }^{7}$ Id, p. 46.
} 
who have tried to put it in those terms have generally stated that it is much higher than the civil standard of 0.5 probability. ${ }^{8}$

Even if the problem of defining the standard could be overcome, there are a host of issues that inevitably stem from the very nature of human decisionmaking. Although fact-finders may do their level-best to base their decisions according to the dictates of the law, there are certain extraneous factors that will affect their decisions. ${ }^{9}$ All these issues attest to the fact that the ultimate decision in a criminal case will be affected by factors external to the legal system itself. Properly defining the standard of proof will do little to dispel these issues because the standard aims at setting the final degree of certainty required of decision-makers while these factors will entail a variation on the starting point for analysis. Even if we were to succeed in our attempt to define what is meant by the beyond a reasonable doubt standard, some lingering problems that are embedded in the decision-making process remain. This by no means suggests that such an attempt is futile; it merely points out that defining the standard is not a panacea to the problems. We would go a long way in the right direction if we manage a more precise definition of the standard of proof in a legal system as it will help to significantly reduce, if not do away with, the element of arbitrariness.

\subsection{Scope of the Standard}

When we say the prosecutor has the burden to prove the crime beyond a reasonable doubt, it implies that each element of the crime needs to be proved by this high threshold. What constitutes 'elements of the crime' is a matter to be determined by the substantive criminal law. While this is the general rule, there are certain issues that are considered exceptions to it. The two main areas that

${ }^{8}$ See, for example, Robert D. Bartels (1981), "Punishment and the Burden of Proof in Criminal Cases: a Modest Proposal", 66 Iowa Law Review 899, p. 900.

${ }^{9}$ See Jack B. Weinstein and Ian Dewsbury (2006), "Comment on the Meaning of 'Proof Beyond a Reasonable Doubt'", Law, Probability and Risk, (Advance Access publication on January 15, 2007), p. 6; They identified the following external factors affecting the decision of judges:

- personal experience,

- degree of confidence in the police, the prosecutor, the court and the justice system as a whole,

- perception of the danger of the moment,

- defendant's past crimes or problematic life style,

- beliefs about the future dangerousness of the defendant. 
raise issues of compatibility with the principle are: presumptions, and affirmative defenses. ${ }^{10}$

\subsubsection{Affirmative Defenses}

Writing about the English law of evidence, Emson notes that '[A]s a general rule, the prosecution are obliged (i) to prove that the accused committed the actus reus of the offence with the requisite mens rea and (ii) to disprove any defense (in respect of which the accused has discharged a mere evidential burden). ${ }^{11}$ The accused is required to discharge an evidential (and not legal) burden when it comes to affirmative defenses. ${ }^{12}$ Therefore, in addition to proving the elements of a crime, the prosecutor need also prove the absence or non-applicability of any defenses the accused may raise.

Murphy argues that '...such cases do not violate [the beyond a reasonable doubt standard]... because the accused is not called upon to disprove any essential element of the charge; they merely provide that if he raises an affirmative defense or an issue of his own, he may be called upon to prove or adduce evidence in support of such defense or issue." $"$ The House of Lords in 2009 similarly held that provisions that put on the accused an evidential burden to prove affirmative defenses were compatible with the notion of presumption of innocence found in the European Convention on Human Rights. ${ }^{14}$

\subsubsection{Presumptions}

As regards the effect of presumptions on the burden of proof, Murphy notes two views. ${ }^{15}$ According to the first view, a presumption creates an evidential burden on the opponent i.e. 'the presumed fact will be taken as proved unless the opponent produces some evidence to rebut the presumption. ${ }^{16}$ If the opponent succeeds in doing this, the normal burden of proof comes to be applied as if the presumption never existed. The second view, on the other hand, holds that a presumption has the effect of shifting the legal burden of proof of the presumed fact to the opponent who will be required to disprove it to the applicable

${ }^{10}$ See Vivian Deborah Wilson (1980), "Shifting Burdens in Criminal Law: A Burden on Due Process", Hastings Constitutional Law Quarterly, Vol. 8, Issue 4, p. 733; Chief Justice M. Monir (2006), Textbook on the Law of Evidence $7^{\text {th }}$ Ed., (New Delhi: Universal Law Publishing), p. 55.

${ }^{11}$ Raymond Emson (2004), Evidence $2^{\text {nd }}$ Ed., (Basingstoke: Palgrave Macmillan), p. 424.

12 Gavin Dingwall (2002), "Statutory Exceptions, Burdens of Proof and the Human Rights Act 1998", Modern Law Review, Vol. 65, Issue 3, p. 451.

${ }^{13}$ Peter Murphy (2007), Murphy on Evidence 10th Ed., (Oxford University Press), p. 82.

${ }^{14}$ Dingwall, supra note 12, p. 451.

${ }_{16}^{15}$ Murphy, supra note 13, p. 74.

${ }^{16}$ Ibid. 
standard of proof. However, this distinction is relevant only to civil cases because in criminal cases presumptions do not have the effect of shifting the legal burden of proof. When a presumption is applied in a criminal case, it will only have the effect of shifting the evidential burden to the accused. ${ }^{17}$

Since presumptions in criminal proceedings raise issues of compatibility with the presumption of innocence and the beyond a reasonable doubt standard, different jurisdictions have come up with certain criteria that must be met for a presumption to be found in line with these notions. The US Supreme Court, for example, developed several tests such as "comparative convenience" and "rational connection." 18 The European Court of Human Rights also stated that the European Convention does not prohibit the use of presumptions, but that they should be kept 'within reasonable limits which take into account the importance of what is at stake and maintain the rights of the defense. ${ }^{19}$ The British jurisprudence on the matter, recognizing that the presumption of innocence is not absolute, reflects a two-stage test to check if the exceptional measure of shifting the evidential burden of proof to the defendant is justified: a clear and proper public objective and a reasonable relationship of proportionality. ${ }^{20}$

Despite the justifications and explanations given by courts and writers, the issues discussed above pose at least a theoretical problem since shifting the evidential burden of proof goes contrary to the requirement that the prosecution prove all elements of the crime by a high degree of proof. They result in an unequal treatment between cases in which these 'exceptions' come into operation and other ordinary cases. Let us take a murder case as an example. Ordinarily the prosecutor would be required to prove- beyond a reasonable doubt- every element of the crime of homicide against the defendant. If, on the other hand, the defendant is to raise self-defense as a justification, he will bear the evidential burden having to prove it, as some argue, on the balance of probabilities standard. In this latter case we are implying that a wrongful conviction and a wrongful acquittal are equally undesirable errors thereby contradicting the very purpose of the standard of proof being set high in criminal cases. $^{21}$

${ }^{17}$ Id., p. 75.

${ }^{18}$ Wilson, supra note 10, p. 742.

${ }^{19}$ Salabiaku v. France, 13 EHRR, (1988), p. 379.

${ }^{20}$ Dingwall, supra note 12, p. 457.

${ }^{21}$ Laudan, supra note 1, p. 113. 


\section{The Standard of Proof in Criminal Proceedings in the Ethiopian Legal System: The Normative Framework}

The standard of proof in criminal proceedings is not clearly stipulated in any piece of Ethiopian legislation. The absence of a codified and comprehensive law of evidence in Ethiopia requires us to explore the diverse substantive and procedural laws in order to examine a particular evidentiary notion such as the standard of proof. Studying this standard in criminal proceedings requires a discussion of the related concept of presumption of innocence of the accused.

The beyond reasonable doubt standard is a definitional element of the notion of 'presumption of innocence' of the defendant in criminal proceedings. By requiring that the fact-finder begins his inquiry 'with a skeptical mindset', presumption of innocence ensures that such presumption is rebutted if and when the prosecution proves the guilt of the defendant by a high standard of proof namely the beyond a reasonable doubt standard. The presumption of innocence is a fundamental principle that has gained recognition in a number of countries with diverse legal systems. ${ }^{23}$

Since the presumption defines the starting point of the fact-finding at trial, it necessitates the introduction of powerful evidence to prove the contrary i.e. the guilt of the accused. As Chambers notes, 'the presumption of innocence and reasonable doubt work in tandem to produce sound verdicts while serving similar, but not identical, purposes... ${ }^{24}$ As will be subsequently argued, therefore, in a legal system where presumption of innocence is recognized, the beyond reasonable doubt standard follows as the standard of proof required of the prosecution to prove guilt before the court can lawfully convict the defendant. This section examines the laws and other instruments in the Ethiopian legal system relevant to the issue of standard of proof in criminal proceedings.

\subsection{The FDRE Constitution}

The Constitution of the Federal Democratic Republic of Ethiopia (FDRE) recognizes the principle of presumption of innocence in no uncertain terms. It provides that "[d]uring proceedings accused persons have the right to be presumed innocent until proved guilty according to law..." 25 There is a discrepancy between the Amharic and English versions of this constitutional

${ }^{22}$ Henry L. Chambers, Jr. (1998), "Reasonable Certainty and Reasonable Doubt", Marquette Law Review, Vol. 81, No. 3, p. 18.

${ }^{23}$ Ibid.

${ }^{24}$ Id, p. 20.

25 Constitution of the Federal Democratic Republic of Ethiopia, Proc. No. 1/1995, (Hereinafter the FDRE Constitution). Art. 20 (3). 
provision. Roughly translated the Amharic states that accused persons have the right 'not to be presumed guilty in legal proceedings' ${ }^{26}$ This is also the protection accorded to the accused under the previous constitutions and is much narrower than the concept of presumption of innocence. Although the Amharic is the binding version, ${ }^{27}$ we must look into whether this discrepancy in terminology is an intentional measure or a mere semantic error.

The rights and freedoms found in the Third Chapter of the Constitution are to be interpreted in light of the Universal Declaration of Human Rights (UDHR) and the International Covenants on Human Rights and international instruments adopted by Ethiopia. ${ }^{28}$ The UDHR, ICCPR and several other international instruments recognize the right of the accused to be presumed innocent. ${ }^{29}$ According to these international instruments and the FDRE Constitution, this presumption of innocence will be rebutted when the defendant is 'proved guilty according to the law', but they do not specify the standard of proof. The Human Rights Committee has discussed the meaning of presumption of innocence under General Comment 32 in which it clarified the obligation of states parties to the Covenant by specifying that the presumption requires the prosecution to prove the charge and '...guarantees that no guilt can be presumed until the charge has been proved beyond reasonable doubt... ${ }^{30}$ (emphasis added). The beyond a reasonable doubt standard can, therefore, be regarded as part of the constitutionally guaranteed right of the accused to be presumed innocent.

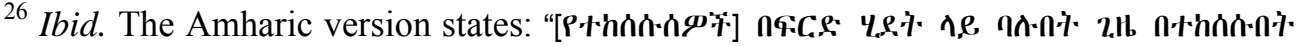

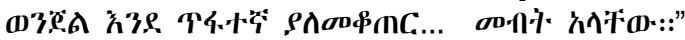

${ }^{27}$ FDRE Constitution, Art. 106.

${ }^{28}$ FDRE Constitution, Art.13 (2).

${ }^{29}$ See Universal Declaration of Human Rights, (10 December 1948, 217 A (III)), Art. 11 (1); International Covenant on Civil and Political Rights, (16 December 1966, United Nations, Treaty Series, Vol. 999), Art.14 (2); African Charter on Human and People's Rights Art. 7(1)(b); African Charter on The Rights and Welfare of the Child Art. 17(2)(c)(i); European Convention on the Protection of Human Rights and Fundamental Freedoms

Art. 6(2); Convention on the Rights of the Child Art. 40(2)(b)(i); Body of Principles for the Protection of All Persons under Any Form of Detention or Imprisonment Principle 36(1).

${ }^{30}$ UN Human Rights Committee (2007), General comment no. 32, Article 14, Right to equality before courts and tribunals and to fair trial, (23 August 2007, $\mathrm{CCPR} / \mathrm{C} / \mathrm{GC} / 32$ ), para. 30 . 


\subsection{The Criminal Procedure Code}

Promulgated in 1961, the Criminal Procedure Code is still applicable as the basic procedural law regulating criminal proceedings in Ethiopia. ${ }^{31}$ It has predominantly adopted the adversarial system and is influenced by the Malayan Code of Criminal Procedure. ${ }^{32}$

The rules governing trial do not clearly stipulate the degree of proof that is required. There are, however, some provisions from which inferences can be made. After the case for the prosecution is concluded, the court is to weigh the presented evidence. ${ }^{33}$ Upon such evaluation, if it finds that what is presented by the prosecution (if unrebutted) would not suffice for a guilty verdict, then the court is to enter an order of acquittal without the need to call the accused to defend himself. If on the other hand, the prosecution's evidence is found sufficient to warrant conviction, then the accused will be called to enter into his defense. ${ }^{34}$ Article 141 reads: "When the case for the prosecution is concluded, the court, if it finds that no case against the accused has been made out which, if unrebutted, would warrant a conviction, shall enter an order of acquittal." 35 The

${ }^{31}$ Since the power of promulgating the procedural laws (civil or criminal) is not listed as a federal power in the Constitution, it is arguably within the mandate of the Regional States to enact their own criminal procedure laws. However, no Regional State has passed its own law of criminal procedure to date nor has the federal government enacted a law on the matter; hence the 1961 Code remains the major law that is operational and governs the process of criminal litigation all over the country. It is important to note that even if no other comprehensive law has been promulgated, there are pieces of legislation, both federal and regional, that provide for certain areas in deviation from, or in addition to the Code. See, Wondwossen Demissie Kassa (2012), Ethiopian Criminal Procedure: A Textbook, (Addis Ababa: American Bar Association), p. 22-23.

32 Stanley Z. Fisher (1969), Ethiopian Criminal Procedure, A Sourcebook (Addis Ababa: Haile Selassie I University), introduction, p. xii.

${ }^{33}$ Worku Yaze explains "The court is supposed to assess the evidence adduced by the prosecution and foresee the probable outcome in case the accused fails to adduce defense and evidence. That is, in order for the court to order the accused to enter into his defense, the court should weigh the evidence adduced by the prosecution and, on the basis of the evidence, it should be convinced that it would automatically convict the accused in case he has no defense" Worku Yaze Wodage (2010), "Presumption of Innocence and the Requirement of Proof Beyond Reasonable Doubt: Reflections on Meaning, Scope and their Place under Ethiopian Law" in Wondwossen Demissie (Ed.), Human Rights in Criminal Proceedings: Normative and Practical Aspects, Ethiopian Human Rights Law Series, Vol. III, p. 128.

${ }^{34}$ Criminal Procedure Code of Ethiopia, Proclamation 185/1961, (hereinafter Cr. Pro. Code), Art. 142. Cr. Pro. Code, Art. 142.

${ }^{35}$ Cr. Pro. Code, Art. 141. 
Amharic, roughly translated, states: 'After the public prosecutor concludes his case, if it is found that [the evidence] is insufficient to find the defendant guilty without the need to present evidence to rebut it and if the court finds the evidence [of the prosecution] insufficient, the court shall order the acquittal of the accused' (emphasis added). ${ }^{36}$ The question then is what the Code means by evidence that 'would warrant a conviction'. ${ }^{37}$

As discussed above, the Criminal Procedure Code was greatly influenced by the Malayan Code of Criminal Procedure. Article 141 of our Code is a verbatim copy of Section 180 of the Malayan Code which provides for the same procedure. ${ }^{38}$ It is thus safe to conclude that this provision in our Criminal Procedure Code was meant to carry the same meaning as its Malayan counterpart. In explaining the meaning of Section 180 of the Malayan Code, Fisher cites a case entertained by the High Court of Malaya in 1946. In this case, the Court reasoned that it is the duty of the prosecution to prove the guilt of the accused and 'only evidence beyond all reasonable doubt' is sufficient to warrant conviction. ${ }^{39}$ Given its close connection with this Code and the special similarity of this particular provision, one may argue that the Ethiopian Criminal Procedure Code also had the beyond a reasonable doubt standard in view. This is buttressed by the fact that the Code was fashioned after the adversarial system of procedure in which this standard is an established norm. Therefore, there are strong reasons to conclude that the Criminal Procedure Code provision is to be understood as implying the beyond a reasonable doubt standard.

Because of British influence in the country since 1941, such adversarial elements in the Ethiopian legal system were prevalent. ${ }^{40}$ Since we now have a

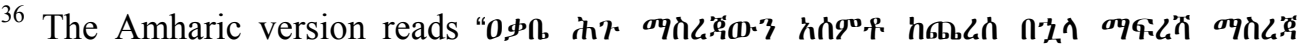

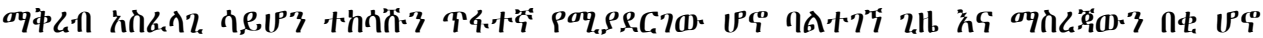

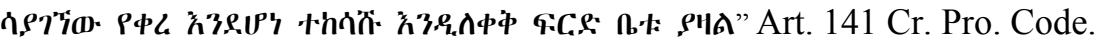

37 Relying on a contrario reading of the Amharic version of this provision, some argue that what is implied in this provision is the 'clear and convincing' standard of proof; some court decisions also reflect this standard.

38 Sec. 180 of the Malayan Code of Criminal Procedure reads: "When the case for the prosecution is concluded, the Court, if it finds that no case against the accused has been made out which if unrebutted would warrant his conviction, shall record an order of acquittal, or if it does not so find, shall call on the accused to enter on his defense." in Fisher, supra note 32, p. 311.

39 Ibid.

${ }^{40}$ Simeneh Kiros Assefa (2012), "The Principle of the Presumption of Innocence and its Challenges in the Ethiopian Criminal Process", Mizan Law Review, Vol. 6, No. 2, pp. 293- 294. Note: The corresponding standard of proof used in inquisitorial systems is what's known as conviction in time of the judge. Similar to the beyond reasonable doubt standard, this sets the bar high for the prosecution to prove the crime by requiring the judge to favor the defendant in cases of doubt. See Mirjan R. Damaska 
constitutional provision upholding the principle of presumption of innocence, the argument for applying this standard is all the more relevant.

The other issue that needs to be addressed is what degree of proof is required of the defendant to rebut the evidence of the prosecution once he is called to enter into his defenses. It is argued that the accused need only produce evidence that would taint the prosecution's evidence with reasonable doubt; he is not required to prove more. ${ }^{41}$ When the case for the defense is concluded, the court is to give its final judgment on the guilt of the accused. ${ }^{42}$ Hence, on the conclusion of all the evidence, first by the prosecutor and then by the defendant, if the court finds that there exists a reasonable doubt as to the guilt of the accused then it is to acquit him; but if his guilt has been established by the prosecutor beyond a reasonable doubt, then the defendant will be found guilty as charged.

\subsection{The Draft Evidence Rules}

The Draft Evidence Rules was a document prepared in 1967 that never came into force. It was meant to supplement the Criminal Procedure Code of 1961 and the Civil Procedure Code of 1965. Although not a binding source of law, it has influenced the Ethiopian legal community and court decisions in terms of providing a reference for basic evidentiary notions. It still forms the major part of what law students study in their law of evidence classes.

Article 81 of the Draft states that the burden of proof lies on the party who wishes to rely on the facts he asserts. ${ }^{43}$ In light of the provisions of the Criminal Procedure Code, the burden of proof in criminal cases lies on the prosecution. Based on the provision discussing exceptions to the burden of proof in criminal cases, ${ }^{44}$ we can infer the following points: (1) The Draft Evidence Rules recognize the beyond a reasonable doubt standard; (2) What is required of the accused while rebutting the case presented by the prosecution when called to enter into his defenses is to raise reasonable doubts about what is presented by the prosecutor, nothing more; (3) If the accused wishes to rely on any legal exception, he will bear the evidential burden of proof (while the legal burden remains with the prosecutor); and (4)The prosecution bears the burden of proving each and every element of the charged crime.

(1973), "Evidentiary Barriers to Conviction and Two Models of Criminal Procedure: A Comparative Study", Faculty Scholarship Series, Paper 1591, p. 558, available at $<$ http://digitalcommons.law.yale.edu/fss_papers/1591>

${ }^{41}$ Worku, supra note 33, p. 130.

${ }^{42}$ Cr. Pro. Code, Art. 149.

${ }^{43}$ Draft Evidence Rules, Art. 81, (1960 E.C., Unpublished).

${ }^{44}$ Id., Art. 84. 


\subsection{The Criminal Justice Administration Policy}

The Criminal Justice Administration Policy was adopted by the Council of Ministers in March 2011 to direct basic governmental actions and decisions in enforcing the criminal justice system in line with constitutional principles, rules and values. ${ }^{45}$ Its objectives include improving the various aspects of the criminal justice system and providing indicators for laws within the system that need to be introduced and others that need amendment. ${ }^{46}$

In outlining the principles and strategies on which it is based, the Policy confirms the commitment to uphold and enforce constitutional rules and principles as well as the various international legal instruments to which Ethiopia is a party. 'The decision-making process in criminal proceedings', it continues, shall be one in which 'the innocent are properly sorted out apart from the guilty. ${ }^{47}$ The Policy is applicable on all bodies and institutions that take part in criminal matters and the criminal justice system. ${ }^{48}$

Part Four of the policy contains provisions that are meant to improve the effectiveness and fairness of the criminal justice system. In a section titled 'circumstances under which the burden of proof may shift to the accused', it envisages the possibility that the defendant may be required to prove his innocence after the public prosecutor has ascertained only certain basic facts. ${ }^{49}$ However, the procedure that is laid down under our Criminal Procedure Code and the presumption of innocence dictate otherwise.

The purpose of the notion of presumption of innocence and setting the standard of proof as high as the beyond a reasonable doubt standard is to protect innocent individuals from wrongful convictions. It stems from the assumption that it is better to err on the side of impunity rather than find an innocent person guilty. And this is because of the serious consequences that may result from the case as well as the stigma associated with being a convict. The more serious the crime, the more we must insist on the proper enforcement of this high standard (since serious crimes entail dire consequences such as long incarceration or even death). The Criminal Policy, on the other hand, has allowed relaxing of this standard in some of the most serious crimes in our system.

${ }^{45}$ Council of Ministers of the FDRE (2011), The Criminal Justice Administration Policy of 2011, (Hereinafter Crim. Policy), Sec. 1.1; For a detailed discussion of this policy and its implications, see generally, Simeneh, supra note 40, pp. 282- 284.

${ }^{46}$ Crim. Policy, Sec. 1.3.

${ }^{47}$ Id., Sec. 1.4.

${ }^{48}$ Id., Sec. 1.6.

${ }^{49}$ Id., Sec. 4.4. 


\subsection{The Draft Criminal Procedure Code}

The drafting of a new code of criminal procedure has been underway for a number of years now. It is meant to be applicable in both Federal and State courts in the country. ${ }^{50}$ The draft has undergone several revisions and substantial changes may take place before it is submitted to parliament and possibly become a binding law. The following discussion is based on the Draft by the Ministry of Justice as it stood in 2003 E.C. (2011) and numerous changes may have been made to it since. Its provisions relating to the issue of burden and standard of proof are discussed here as useful indicators of where our law is generally headed in dealing with these issues.

The Draft reiterates the constitutional principles of presumption of innocence and freedom from self-incrimination. ${ }^{51}$ It states that the prosecution bears the burden to prove and ascertain the crimes charged while the accused has the right to defend himself. However, the same provision goes on to provide for exceptions to this rule. It states: "Notwithstanding the principle [set above] where the accused is charged with crimes against the constitutional order, terrorism, corruption or conspiracy, or when the law provides, the burden of proof may shift to the accused upon the prosecution proving the primary facts." ${ }^{, 52}$ Another provision adds that the accused shall bear the burden of proof if he wants to rely on an affirmative defense or to prove alibi. ${ }^{53}$ The Draft further stipulates that 'it shall be considered that the accused has committed the offence when the charge has been proved sufficiently. ${ }^{54}$ The court is to record a verdict of not guilty and acquit the defendant when the prosecutor fails to prove the charge sufficiently or the defendant, through his evidence, sufficiently proves that he did not commit the crime. ${ }^{55}$

Although this Draft has accomplished the commendable task of filling the multiple gaps found in the 1961 Criminal Procedure Code, it still leaves many questions unanswered in relation with burden and standard of proof. In providing exceptions to the rule that the prosecution bears the burden of proof, it does not specify whether it is the legal or the evidential proof that shifts to the

${ }^{50}$ Ministry of Justice (2003 E.C), Draft Criminal Procedure Code, (Unpublished, Amharic), Preamble, Art. 1.

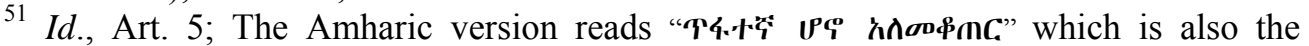
expression the FDRE Constitution uses under Art. 20(3) to describe presumption of innocence.

${ }_{53}^{52}$ d., Art. 5(3).

${ }^{53}$ Id., Art. 380.

${ }^{54}$ Id., Art. 396.

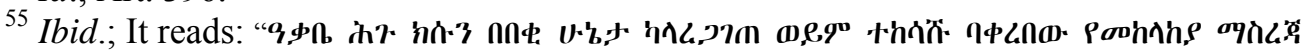

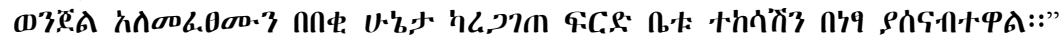


defendant. ${ }^{56}$ It allows such shift in very serious crimes such as terrorism. In stipulating the requisite standard of proof, it simply provides that the charge needs to be 'sufficiently proved' which is far from an adequate description. What does 'sufficient' mean? Should the court convict the accused on the balance of probabilities or do we require a higher standard? It further states that the court is to acquit the defendant when he 'sufficiently proves that he did not commit the crime.' This clearly deviates from the presumption of innocence and the principle that the prosecution bears the burden of proof, to which the Draft Criminal Procedure Code claims to be committed. The Draft has thus failed to discharge its expressly stated objectives of upholding constitutionally guaranteed rights of individuals.

\section{Presumptions in Ethiopian Criminal Law}

Ethiopia's 2004 Criminal Code stipulates that "[a] crime is only completed when all its legal, material and moral ingredients are present." ${ }^{57}$ The same provision which indicates the legal, material and moral elements of a crime states that "[a] crime is punishable where the Court has found the crime proved and deserving of punishment." ${ }^{58}$ A joint reading of these two stipulations shows us that all the three elements have been proved for a Court to find it proved and 'deserving of punishment'. Art. 57(1) of the Code reiterates the requirement of the existence of the mental element by stating: "No one can be punished for a crime unless he has been found guilty thereof under the law. A person is guilty if, being responsible for his acts, he commits a crime either intentionally or by negligence." And since, as discussed under Section 2 above, the requisite standard of proof for criminal proceedings in the Ethiopian legal system, is expected to be beyond a reasonable doubt, all the three elements of a crime need to be proved at the thresholds of this standard. ${ }^{59}$

There are, however, some provisions that presume the existence of one or more of these three ingredients thereby relieving the prosecution from the need to prove them. One such provision is Article 43 that provides for 'liability for

56 Although these two are theoretically distinct, one scholar validly questions the practical significance of distinguishing between the two when the evidential burden is shifted to the accused. He argues, since it is nearly impossible for the defendant to discharge this burden, it is equivalent to requiring him to bear the legal burden. See Dingwall, supra note12, p. 457.

${ }^{57}$ Criminal Code of the Federal Democratic Republic of Ethiopia, Proc. No. 414/2004, (Hereinafter Cr. Code), Preamble, Art.23(2).

${ }_{58}^{58}$ Cr. Code, Art. 23(4).

${ }^{59}$ For a detailed discussion of elements of a crime that need to be proved beyond a reasonable doubt See Simeneh, supra note 40, pp. 289-291 (Sec. 2.2.1.). 
crimes committed through the mass media' ${ }^{60}$ By presuming the existence of the moral element of the crime, the provision not only relieves the prosecutor from having to prove it, but also forbids the defendant from introducing any evidence to prove its absence.

A provision headed 'Presumption of intent to obtain advantage or to injure' also equates the material element with the criminal act and relieves the prosecutor of the need to prove the mental element of the crime- an essential ingredient that needs proof as per Art. 23 of the Code. ${ }^{61}$ In this connection Simeneh has noted that ' ...this presumption is rebuttable and the defendant may produce contrary evidence. However, disproving a presumed state of mind is more difficult than proving it. Thus, the burden on the defendant is unreasonable. ${ }^{62}$ Article 419 on 'Possession of unexplained property' also requires the defendant to give a 'satisfactory explanation' of the sources of such income/property for possession of which he was charged. ${ }^{63}$

Article 477 of the Code criminalizing 'Dangerous vagrancy' raises some questions. According to this provision, a person may be found guilty of this crime when the prosecution proves that such person possessed 'weapons or instruments fitted by their nature to the commission of a crime. ${ }^{64}$ Another provision on the use of poisonous or narcotic and psychotropic drugs also criminalizes any person who 'plants, buys, receives, makes, possesses, sells or delivers' these substances. ${ }^{65}$ At first glance these words may seem to require the prosecutor to prove intention. But a question arises whether it is sufficient to prove (beyond a reasonable doubt) that the defendant intentionally planted, bought or possessed such substance, or whether the prosecutor should go on to prove that the defendant knew of the nature of the substance under his control. Moreover the question as to who bears the burden of proving that the accused had this knowledge deserves attention. These provisions seem to imply that

${ }^{60}$ Cr. Code, Art. 43(5).

${ }^{61} \mathrm{Cr}$. Code, Art. 403; it reads "Unless evidence is produced to the contrary, where it is proved that the material element (the act) has been committed as defined in a particular Article providing for a crime of corruption perpetrated to obtain or procure undue advantage or to cause injury, such act shall be presumed to have been committed with intent to obtain for oneself or to procure for another an undue advantage or to injure the right or interest of a third person."

${ }^{62}$ Simeneh, supra note 40, p. 304.

${ }^{63}$ The Cassation Bench of the Federal Supreme Court has given a recent ruling on this provision which is discussed in Section 4.

${ }^{64}$ Cr. Code, Art. 477(2); See also Vagrancy Control Proclamation, Proc. No. 384/2004, Art. 4 expanding on the definition of 'Vagrancy'.

${ }^{65}$ Cr. Code, Art. 525 (4)(a). 
knowledge of the nature of the object is presumed and it is up to the defendant to prove the absence of such knowledge.

Some controversies have ensued from similar provisions found in the laws of other countries. Criticizing the Misuse of Drugs Act 1971 of England (which also stipulated that possession was to be criminalized), Dingwall wrote: ${ }^{66}$

... [P]ossession is an inherently 'neutral' concept that does not in itself carry any implication of moral blameworthiness. [The requirement of 'possession' under... the... Act 1971] is in effect an offence of strict liability as there is no further mens rea requirement that the defendant has to be aware that the item he was in possession of is a controlled drug.

Yet another provision that introduces a presumption against the defendant is found in Art. 675(3) according to which the mental element of intent to obtain... an unjustifiable enrichment' required for this crime of breach of trust is presumed to exist where the defendant is 'unable upon call, to produce, or repay the thing or sum entrusted...67

In addition to the crimes specified in the Criminal Code, other pieces of legislation promulgated over the years have added to the list of offences that are punishable as crimes in Ethiopia. Some of these proclamations have some import on the issue of standard of proof. The Anti-Corruption Proclamation of 2005 contains a provision on the standard of proof that is required to prove that the defendant 'benefited from criminal conduct' and proof of 'the amount to be recovered.' In these cases, the provision holds that the standard of proof 'shall be that applicable in civil proceedings. ${ }^{98}$ The prosecutor need only show the existence of some basic facts for the evidential burden to be shifted to the defendant; the accused is then expected to rebut the presumption of guilt that stands against him. ${ }^{69}$

Likewise, the Value Added Tax Proclamation provides that the manager of an entity 'is treated as having committed the offence [with which the entity itself is charged] and is liable to a penalty under this proclamation. ${ }^{, 70}$ It provides an exception to this rule by stating that the person will not be liable if the crime was committed without his knowledge or consent and if the person exercised 'the degree of care, diligence and skill that a reasonably prudent person would

${ }^{66}$ Dingwall, supra note 12, p. 454.

${ }^{67}$ Cr. Code, Art. 675 (3).

${ }^{68}$ Revised Anti-Corruption Special Procedure and Rules of Evidence Proclamation, Proc. No. 434/2005, Art. 33.

${ }^{69}$ See, generally, Hiwote Mekonnen (2001), Burden of Proof and Standard of Proof under the Anti-Corruption Special Procedure and Rules of Evidence Proclamation, (Faculty of Law, AAU, Unpublished).

${ }^{70}$ Value Added Tax Proclamation, Proc. No. 285/2002, Art. 56(1). 
have exercised in comparable circumstances to prevent the commission of the offence. ${ }^{71}$ Although it does not specify who is to prove this exception, it is presumably up to the defendant to show the existence of these facts. The Turnover Tax and the Excise Tax proclamations also contain similar provisions. $^{72}$

The presumptions contained in these legislations have the effect of shifting the evidential burden of proof to the accused and he is required to adduce evidence to prove otherwise. ${ }^{73}$ Similar legislations that shift the evidential burden of proof to the defendant are found in other legal systems that recognize presumption of innocence and the principle of proof beyond a reasonable doubt. In a case contesting such a law in England, the House of Lords held that the presumption of innocence protected in the European Convention of Human Rights is not absolute and hence, not every reverse burden of proof would be contrary to the Convention. ${ }^{74}$ The European Court of Human Rights similarly held that provisions containing a reverse burden of proof can be compatible with the presumption of innocence as long as they are 'confined within reasonable limits which take into account the importance of what is at stake and maintain the rights of the defense. ${ }^{75}$ The Privy Council found such limitation on the right to be presumed innocent as an 'implicit flexibility' that 'allows a balance to be drawn between the interest of the person charged and the state.' 76

The recognition of presumption of innocence under the FDRE Constitution, some argue, is an absolute right that admits no limitations. ${ }^{77}$ For proponents of

${ }^{71}$ Id., Sub. 3.

72 See Turnover Tax Proclamation, Proc. No. 308/2002, Art. 33; Excise Tax Proclamation, Proc. No. 307/2002, Art.24; Customs Proclamation, Proc. No. 622/2009, Art.92(3). See also, The National Bank of Ethiopia Establishment Proclamation, Proclamation No. 591/2008, Art. 26.

${ }^{73}$ Here the standard of proof required of the defendant is the civil standard of 'preponderance of evidence.'

${ }^{74}$ Emson, supra note 11, p. 428.

${ }^{75}$ Salabiaku v. France (1988) 13 EHRR 379 at 388; Hoang v. France (1992) 16 EHRR 53 at 78 (as quoted in Id., p. 428); Emson lays down certain criteria that need to be met for such provisions to be compatible with the presumption of innocence. Such shifting of legal burden must be: 1.directed towards a legitimate public objective, 2.proportional, and 3. Necessary (in the sense that an evidential burden on the accused would not suffice to achieve the same objectives). (See, generally, Emson, supra note 11 , pp. 427-434).

${ }^{76}$ Attorney-General of Hong Kong v. Lee Kwong-Kut [1993] 3 WLR 329. (as quoted in Id., p. 429).

77 Simeneh, supra note 40, p. 288; the House of Lords however found that the presumption of innocence is not absolute and some derogation in some circumstances is acceptable. (See Dingwall, supra note 12, p. 457). 
this view, these subsequent pieces of legislation that shift the evidential burden of proof to the defendant would be clearly unconstitutional. Even if we were to accept certain limitations to the principle, whether our laws would meet the strict criteria set out for compatibility like those of England is debatable. ${ }^{78}$

\section{The Practice of Ethiopia's Federal Supreme Court (FSC) regarding Standard of Proof in Criminal Proceedings}

After briefly touching on court practice in general in relation to the standard of proof, this section provides a summary of select cases decided by the Federal Supreme Court Cassation Bench and analyzes them to identify their implications on the issue.

\subsection{Court Practice: General Overview}

Although the writer believes that the beyond a reasonable doubt standard is recognized under the Ethiopian legal system, the fact remains that it is nowhere mentioned in any binding legal instrument. The legal academia seems to be of the opinion that the beyond a reasonable doubt standard can be inferred from, inter alia, the constitutional principle of presumption of innocence and hence courts should apply this rigorous standard in criminal cases. ${ }^{79}$ Legal research done in related topics seem to take the existence of the beyond a reasonable doubt standard for granted. ${ }^{80}$ The practice, on the other hand, depicts a completely different picture with various courts using very different formulations of the degree of proof required of the prosecutor to prove the guilt of the defendant. Although one may frequently find the beyond a reasonable doubt in older judgments given by Ethiopian courts, the current trend seems to have digressed from that. Since there has not been a change in the normative standard, such development appears to have stemmed from a change in the attitude of the legal community. As WorkuYaze duly observes: ${ }^{81}$

... plenty of court cases prove that Ethiopian courts and litigating parties ritually invoke proof beyond reasonable doubt. This does not mean, however, that they always employ this same standard, understand what it means and apply it in its proper sense. To the contrary, they use various

\footnotetext{
${ }^{78}$ The House of Lords in England, for example, found that the presumption of innocence is not absolute and some derogation in some circumstances is acceptable. (See Id, p. 457).

${ }^{79}$ See, in general, Worku, supra note 33; Simeneh, supra note 40; Wondwossen, supra note 31 .

${ }^{80}$ See, for example, Hiwote, supra note 69.

${ }^{81}$ Worku, supra note 33, p. 133 (footnote omitted).
} 
expressions including 'beyond doubt', 'beyond the least shadow of doubt', 'absolutely beyond any doubt' and 'beyond reasonable doubt' and so on.

\subsection{The Jurisprudence of the Cassation Bench of the Federal Supreme Court}

Proclamation $454 / 2005$ has rendered interpretations of law by the Federal Supreme Court, Cassation Division binding on federal and regional courts of all levels. ${ }^{82}$ In addition to their significance as part of court practice, therefore, the decisions of the Cassation Bench are binding sources of statutory interpretation on cases that involve similar issues, and other courts are required to abide by the Cassation Bench's interpretations of legal provisions.

Although the Federal Supreme Court Cassation Bench has nowhere clearly stated the standard of proof to be employed in criminal cases, there have been a number of cases brought before it contesting either the sufficiency of evidence upon which lower courts made their decisions or the degree of proof itself. In such cases the Court has rendered its opinion on whether or not the decision of the trial court is justified without however going into an analysis of the standard of proof itself.

We will, here-below briefly look at the relevant parts of thirteen FSC Cassation Bench decisions followed by a brief analysis of their significance and implications. The cases discussed will help us see, not only the position of the Cassation Bench, but also the line of reasoning of various courts from which the Cassation petition is brought.

\subsubsection{Court Decisions}

\section{a) Minase A. v. Public Prosecutor ${ }^{83}$}

The case, charging the defendant with the crime of fraudulent misrepresentation, was first brought before the Benishangul Gumuz High Court, and to the State's Supreme Court on appeal both of which found the defendant guilty as charged. He contested such decision claiming that he was not given the chance to defend himself and brought an application before the FSC Cassation Bench. The Court stated: '[s]ince the guilt of the applicant has been established by sufficient evidence in the lower court, we found that neither the process nor the decision

${ }^{82}$ Federal Courts Proclamation Re-amendment Proclamation, Proc. No. 454/2005, Art.2(4).

${ }^{83}$ Minae A. v. Public Prosecutor (Federal Supreme Court, Cassation File No. 12025) Federal Supreme Court Cassation Bench Decisions, Vol. 4, pp. 115-116. 
shows the existence of a fundamental error of law, ${ }^{84}$ (emphasis added), and it upheld the decisions of the State courts.

\section{b) Kurat T. et. al. v. Public Prosecutor ${ }^{85}$}

The defendants were first brought before the North Gondar High Court in Amhara Region charged with attempted aggravated homicide which, after hearing the prosecution case, acquitted them without calling them to enter into their defenses. The case was brought before the FSC Cassation Bench by the defendants contesting the appellate decision of the Amhara Supreme Court which remanded the case back to the trial court after finding that prosecution witnesses have established the guilt of the accused and that the defendants 'should defend themselves to the extent of their established culpability. ${ }^{86}$ The trial court, after hearing the defense, held that the testimony of the prosecution witnesses has not been rebutted by the defense witnesses and hence found the defendants guilty as charged. The FSC Cassation Bench, after looking into the evidence presented before the trial court, held that the defendants should have been charged under ordinary homicide instead and found them guilty under that provision. $^{87}$

\section{c) Oromia Prosecutor General v. Zerihun T. ${ }^{88}$}

In this case, the trial court- namely the West Wolega Zone High Court of Oromia Region, after hearing the case of the prosecution, acquitted the defendant who was charged for the crime of rape. The court held that the prosecutor failed to establish the facts of the case as found in the charge. On appeal, the decision was upheld by the Oromia Supreme Court and the Cassation Bench of the same court. The public prosecutor brought a petition before the Federal Cassation Bench arguing that the decisions of these three courts were erroneous.

The Court noted that five prosecution witnesses, a police report as well as medical evidence were presented before the trial court. It examined whether the

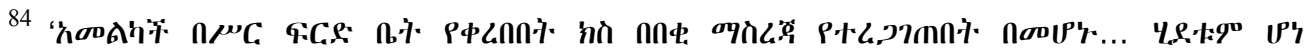

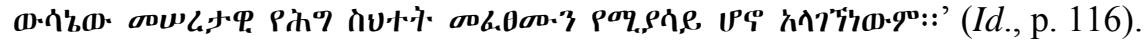

${ }^{85}$ Ato Kurat T. et. al. v. Public Prosecutor (Federal Supreme Court, Cassation File No. 22514) Federal Supreme Court Cassation Bench Decisions, Vol. 7, pp. 262-264.

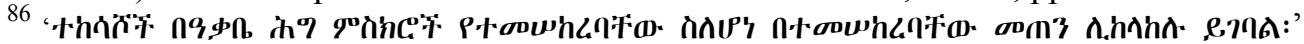
(Id, p. 262).

${ }^{87}$ It based its decision on Art. 113(2) of the Criminal Procedure Code which provides for the case where an accused may be convicted for a crime other than the one charged with if the crime proved by evidence is of lesser gravity and all its elements are also found as elements of the charged crime.

${ }^{88}$ Oromia Prosecutor General v. Zerihun T. (Federal Supreme Court, Cassation File No. 31731) Federal Supreme Court Cassation Bench Decisions, Vol. 7, pp. 278-282. 
prosecution's case was sufficient in light of the legal elements of the crime and concluded that the pieces of evidence presented by the prosecutor are complementary and 'properly establish the occurrence of the offence' (emphasis added) ${ }^{89}$ The Cassation Bench criticized the decision of the trial court for disregarding the prosecution evidence stating that every court must rely on evidence presented to it to decide on the contested issues and reach a decision. It went on to add that in this case the evidence brought forth by the prosecutor 'clearly ascertains the commission of the crime' (emphasis added). And hence the failure on the part of the lower courts to take this evidence into account 'is not only contrary to the law but also very damaging to the cause of justice.' Accordingly the Court quashed the judgments given by the lower courts and ordered that the defendant be called on to defend himself 'since the commission of the crime has been established by the prosecution's evidence. 90

\section{d) Amhara Region Justice Bureau Public Prosecutor v. Kebede W. ${ }^{91}$}

The defendant was charged with the crime of arson and intentional homicide (or negligent homicide in the alternative) and the case was entertained by an Amhara High Court which found the accused guilty of arson and negligent homicide. The Amhara Supreme Court on appeal found that the mental element that constitutes the crime of negligent homicide was not present and found the defendant not guilty of this crime, but upheld the conviction on the crime of arson.

The Cassation Bench in this case found that the Amhara Supreme Court failed to take into account the whole content of the evidence presented by the public prosecutor. It held that such evidence on the whole indicates that the defendant purposely set the house of the victim on fire and that he should also be held liable for negligent homicide for the persons who died.

\section{e) Jamila M. et. al. v. Federal First Instance Public Prosecutor ${ }^{92}$}

The case was first brought before the Federal First Instance Court where the defendants were charged with using arbitrary action to safeguard a right. After recording the defendants' plea of not guilty and hearing the evidence of the

89 ،

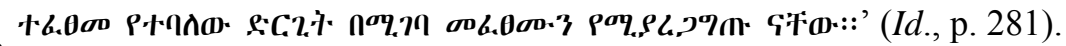

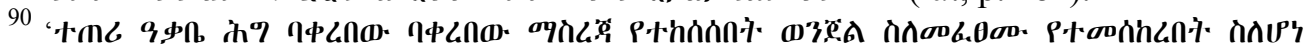

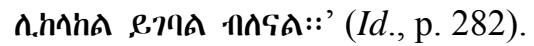

91 Amhara Region Justice Bureau Public Prosecutor v. Kebede W. (Federal Supreme Court, Cassation File No. 35697) Federal Supreme Court Cassation Bench Decisions, Vol. 9, pp. 2-4.

92 Jamila M. et. al. v. Federal First Instance Public Prosecutor (Federal Supreme Court, Cassation File No. 38161) Federal Supreme Court Cassation Bench Decisions, Vol. 9, pp. 11-12. 
prosecution, the trial court ordered the defendants to enter into their defenses. The court then held the accused guilty stating that the evidence presented in defense 'do not suffice to rebut the prosecution's evidence. ${ }^{93}$

Upon the petition presented to it, the Cassation Bench framed the issue on whether or not the action of the defendants constitutes a crime. Citing Article 23 of the Criminal Code, it concluded that not all the three ingredients of the crime are present, and accordingly found that the defendants were free of any criminal liability.

\section{f) Shega M. v. Oromia Region Public Prosecutor ${ }^{94}$}

The petition was brought by the defendants contesting the verdict given by the Oromia High Court finding them guilty of homicide which was confirmed by the Oromia Supreme Court and the Cassation Bench of the same court. In answer to the petition, the prosecutor responded that 'since the applicants' guilt has been established without a doubt through the evidence presented, the verdict as well as the sentence given by the lower court should stand' (emphasis added).

In this case, the Federal Supreme Court Cassation Bench held that it was not within its jurisdiction to go into 'particulars of the offence and weighing of evidence. ${ }^{95}$ The Court looked into whether the action of the defendants would fall under legitimate defense, and concluded that the defendants had not adduced evidence to prove that the elements of such justification exist. Therefore, it found that the defendants should be held liable under extenuated homicide since the circumstances indicate that they exceeded the limits of legitimate defense.

\section{g) Burqeso W. v. Public Prosecutor ${ }^{96}$}

The case was first brought before the High Court in Gamo where the defendant was charged with homicide. The trial court heard the prosecution case and after calling the accused to defend himself, found the accused guilty as charged because he did not present any defense and thus failed to rebut the evidence presented by the prosecution. The defendant, in his petition to the FSC

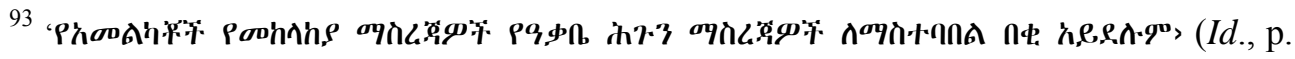
11).

94 Shega M. v. Oromia Region Public Prosecutor (Federal Supreme Court, Cassation File No. 43501) Federal Supreme Court Cassation Bench Decisions, Vol. 10, pp. 196-199.

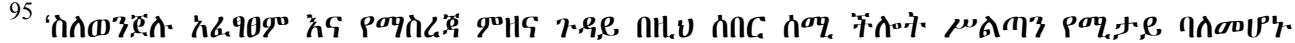

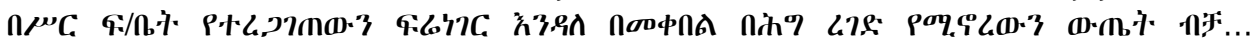
oxC90LGA::' (Ibid.).

96 Burqeso W. v. Public Prosecutor (Federal Supreme Court, Cassation File No. 41248) Federal Supreme Court Cassation Bench Decisions, Vol. 10, pp. 207-208. 
Cassation Bench, claimed that the lower court convicted him 'without the public prosecutor proving guilt beyond a reasonable doubt' and upon false evidence. ${ }^{97}$

The Cassation Bench held that the fact that the applicant committed the criminal offence was appropriately established by the public prosecutor through evidence and ascertained by the lower courts. ${ }^{98}$ It then stated, similarly with the case discussed above, that it was outside its jurisdiction to examine issues involving weighing of evidence and hence rejected the claim of the applicant. ${ }^{99}$

\section{h) Girma T. v. Federal Ethics and Anti-Corruption Commission ${ }^{100}$}

The defendant was charged with a corruption offence, and he brought an application before the Cassation Bench claiming that the public prosecutor had not discharged his burden of proof as required by law and that the evidence produced by the prosecutor in fact proves his innocence. He also contested the decision of the Federal Supreme Court that affirmed the judgment of the trial court. And hence, he argued, the case presented by the prosecution is not sufficient to conclude that he committed the offence and the guilty verdict was based on the false testimony of prosecution witnesses.

The Cassation Bench gave an analysis on the issue of burden of proof in criminal proceedings basing itself on basic principles of evidence law and the applicable legal provisions. It stated that before the defendant is called to enter into his defenses, the court needs to ascertain that the pieces of evidence brought forth by the prosecutor are complementary. Failing this test, it continued, the trial court's decision requiring the accused to defend himself was inappropriate.

From the provisions of Articles 141 and 149 of the Criminal Procedure Code we can gather that the prosecutor has the duty to prove that the defendant

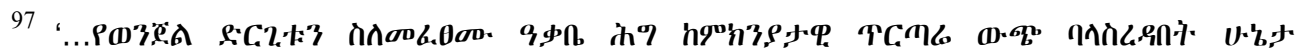

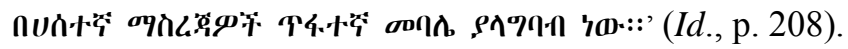

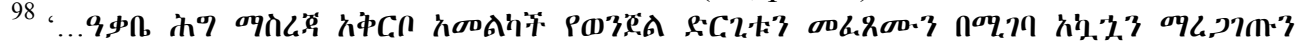

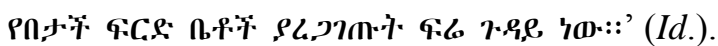

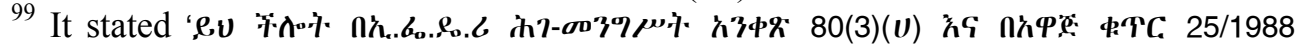

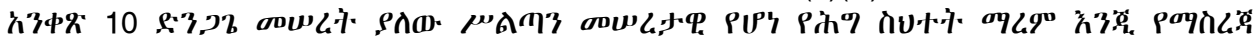

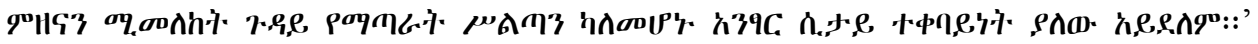
(Id.) The Court reiterated this position that it was beyond its legal mandate to go into weighing of evidence in a number of subsequent cases. In Volume 12 of the Court's Decisions itself, the Court stated this in the following cases: File no. 59855, File No. 52075, File No. 57446, File No. 64813, File No. 61275, File No. 66767, File No. 55649.

100 Girma T. v. Federal Ethics and Anti-Corruption Commission (Federal Supreme Court, Cassation File No. 51706) Federal Supreme Court Cassation Bench Decisions, Vol. 10, pp. 211-218. 
committed the crime mentioned in the charge by sufficient evidence ${ }^{101 .}$ We say that this burden of proof is sufficiently discharged when the evidence presented have reliability and are capable of proving the charge. Reliability of evidence is to be checked by looking at whether it is coherent and does not contain contradictory elements...

After giving the above explanation the Court decided that the public prosecutor had not effectively discharged his burden of proof and ordered that the defendant be set free.

\section{i) Aregahegn M. v. Federal Ethics and Anti- Corruption Commission ${ }^{102}$}

The case was first brought before the Federal High Court which found the defendants guilty of the crime of corruption. The decision was confirmed by the Federal Supreme Court on appeal and one of the defendants brought this petition. In his application for cassation, the defendant contended that the prosecution evidence does not establish his guilt 'beyond the appropriate doubt' ${ }^{103}$, that he was convicted and sentenced simply for giving his legal opinion, and that this constitutes a 'fundamental error of law.' The prosecutor responded by saying that the claim of the applicant involves an issue of fact and not an issue of law, and thus the decisions of the lower courts should be upheld.

The Court did not frame the standard of proof as an issue and instead held that the evidence presented does not constitute the crime of corruption and that the defendant should have been charged under a different provision of 'crimes committed in dereliction of duty'.

\section{j) Oromia Region Public Prosecutor v. Eyosiyas A. et. al. ${ }^{104}$}

The case was first brought before the East Shoa Zone High Court where the first defendant was charged with aggravated homicide involving two victims while the other four defendants were accused for having participated in the offence in different capacities. The trial court passed a guilty verdict for the first and third defendants and found the other three not guilty stating that they had defended themselves. On appeal, the application of the public prosecutor was rejected and

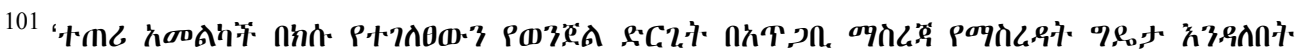

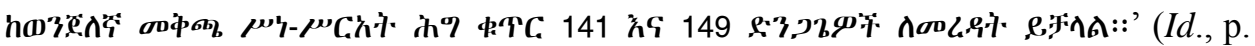
216).

${ }^{102}$ Aregahegn M. v. Federal Ethics and Anti- Corruption Commission (Federal Supreme Court, Cassation File No. 43049) Federal Supreme Court Cassation Bench Decisions, Vol. 12, pp. 217-220.

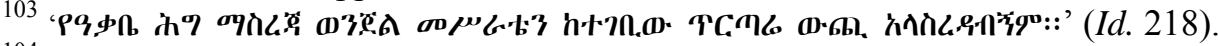

104 Oromia Region Public Prosecutor v. Eyosiyas A. et. al. (Federal Supreme Court, Cassation File No. 45595) Federal Supreme Court Cassation Bench Decisions, Vol. 12, pp. 229-237. 
the Oromia Supreme Court decided that the guilt of the third defendant had not been properly established and set her free. ${ }^{105}$ The prosecutor again appealed to the Cassation Bench of the Oromia Supreme Court which did not accept the claim of the prosecutor and instead held that the first defendant should have been charged under ordinary homicide and reduced his sentence.

In its petition for cassation, the prosecutor contested this last decision concerning the sentence of the first defendant and the verdict of the other four. After framing the issues for each defendant, the Court reversed the decision of the Cassation Bench of the Oromia Supreme Court as regards the first defendant and held that he should be convicted under aggravated homicide as first decided by the trial court. The Cassation Bench gave an analysis of the evidence presented against the second defendant and decided that the lower courts had erroneously acquitted him. It reversed the verdict and convicted him. With regard to the third defendant, the Court noted that the Oromia Supreme Court found that the evidence presented by the prosecutor does not sufficiently establish her participation in the crime. As it had done in a number of cases, it went on to state that weighing of evidence would be beyond the mandate of the court to rectify fundamental error of law; and disregarded the prosecutor's petition against the verdict given on the third defendant. However, the court analyzes the evidence presented before the lower courts. The relevant part of this judgment reads:

The evidence clearly shows that [the third defendant] intentionally aided the first defendant after commission of the offence in order to save him from prosecution and punishment. And this implies criminal responsibility... Therefore, although this Court cannot go into weighing of evidence, [we found that]... the decision of the Oromia Supreme Court, appellate bench finding the third defendant free of criminal responsibility despite what has been sufficiently established... is a fundamental error of law. ${ }^{106}$

The Court gave a similar analysis of the evidence as regards the fourth defendant and reversed the decision of the lower courts finding both the third and fourth defendants guilty of participating in a crime of aggravated homicide.

\section{k) Awet T. v. Tigrai Public Prosecutor ${ }^{107}$}

The accused was convicted for participation in an offence of aggravated homicide along with other criminal defendants before the Eastern Zone High Court of Tigrai Region and the decision was confirmed by the Tigrai Supreme

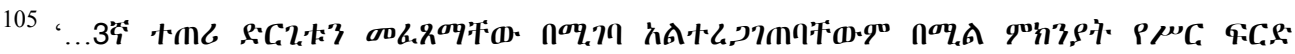

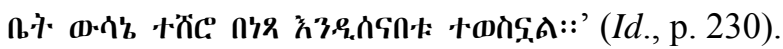

106 Id., p. 234.

107 Awet T .v. Tigrai Public Prosecutor (Federal Supreme Court, Cassation File No. 57644) Federal Supreme Court Cassation Bench Decisions, Vol. 12, pp. 264- 268.
} 
Court as well as the Cassation Bench of the same court. In his petition for cassation, the defendant claimed that the prosecution evidence presented before the trial court does not establish his participation in the crime and that his conviction, in the absence of any evidence establishing his guilt, was a fundamental error of law.

The Cassation Bench noted that the lower courts that had the power to weigh the evidence presented failed to ascertain in their judgments that the prosecutor discharged his burden of proving the elements of the crime under which the defendant was charged for participation. The Court observed that the judgment of the trial court itself shows that the prosecutor did not prove the criminal liability of the defendant by sufficient evidence. ${ }^{108}$ The Cassation Bench stated that the trial court should have acquitted the defendant as per Article 141 of the Criminal Procedure Code without calling on the defendant to enter into his defenses. The Cassation Bench found this decision as one involving a fundamental error of law and reversed it.

\section{1) Afework L. et. al. v. SNNPR Prosecutor ${ }^{109}$}

The defendants were charged with aggravated homicide before the Hawassa High Court. The Court found that although the prosecution did not present any direct evidence, the circumstantial evidence was 'sufficient and convincing to reach a conclusion, 110 and found them guilty of ordinary homicide. The decision was confirmed by the SNNPR Supreme Court. In their petition to the FSC Cassation Bench the defendants claimed that their individual guilt had not been ascertained and that none of the prosecution witnesses were direct witnesses.

The Cassation Bench stated that circumstantial evidence is allowed under the Criminal Procedure Code; and that since the prosecution evidence ascertained that the victim's death was caused by the defendants, they shall not be free from criminal liability whether or not their individual participation was proved separately. ${ }^{111}$ It also stated that the guilty verdict decided by the trial court was something to be deduced from the evidence, and hence falls outside the mandate

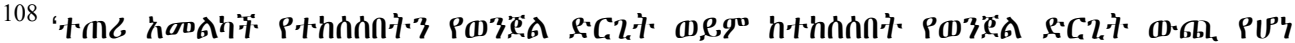

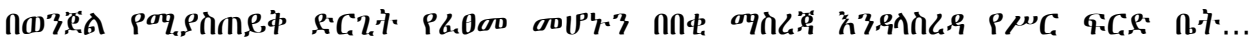

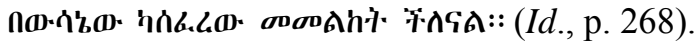

${ }^{109}$ Afework L. et. al. v. SNNPR Prosecutor (Federal Supreme Court, Cassation File No. 75922) Federal Supreme Court Cassation Decisions, Volume 13, pp. 329- 331.

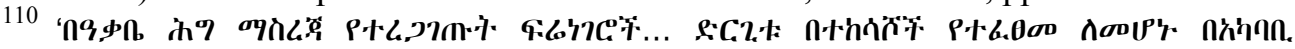

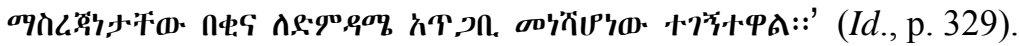

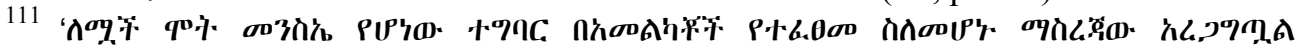

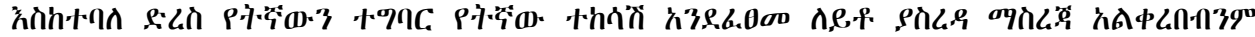

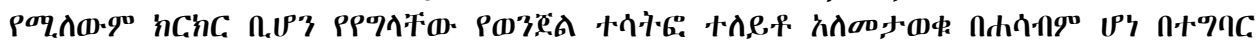

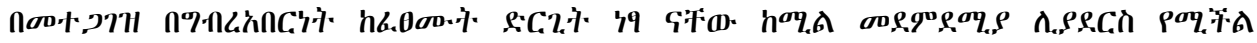

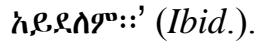


of this court which only looks into issues of law. The Court found that even if it is said that it raises an issue of law in relation to whether it complies with Art. 141 of the Criminal Procedure Code... it does not warrant the conclusion that they should have been acquitted before they were called to enter into their defenses. The Court decided that the defendants' guilt had been ascertained by evidence that meets the standard required by the law of criminal procedure. ${ }^{112}$

\section{m) Workneh K. et.al. v. SNNPR Ethics and Anti-Corruption Commission Prosecutor ${ }^{113}$}

The case was first brought before the Hawassa High Court where the defendants were charged with a corruption crime of 'possession of unexplained property' under the Criminal Code. After hearing the evidence, the trial court acquitted the defendants finding that the evidence they presented rebutted the case of the prosecution. ${ }^{114}$ This decision was confirmed by the SNNPR Supreme Court. The Cassation Bench of this same court reversed these decisions and convicted the defendants stating that the evidence presented by the defense did not have sufficient probative value to rebut the case of the prosecution.

The Cassation Bench of the Federal Supreme Court looked into whether the SNNPR Cassation Bench had the mandate to look into the evidence and render the decision that it did. Basing itself on the provisions of the Federal and Regional constitutions as well as a proclamation of the Region, it found that the SNNPR Cassation Court lacked the jurisdiction to evaluate facts and weigh evidence. The Federal Supreme Court Cassation Bench concluded that the decision given by the SNNPR Cassation Bench has a 'fundamental error of law.'

The Court went further to make a distinction between evaluation of evidence, which lies outside the jurisdiction of cassation, and related issues such as the burden of proof. Since the latter is a question of law, it argued, the Cassation Bench can evaluate the decisions of lower courts and give a decision thereon. The Court examined the elements of Art. 419 of the Criminal Code which criminalizes "possession of unexplained property", in light of the facts of the case. According to this provision it is up to the defendant to give a 'satisfactory explanation' of the source of the property for possession of which he was

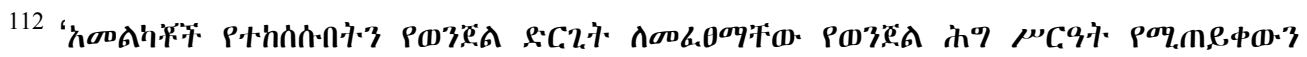

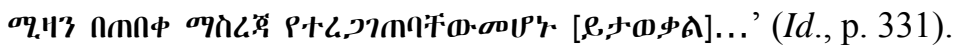

113 Workneh K. et. al. v. SNNPR Ethics and Anti-Corruption Commission Prosecutor (Federal Supreme Court, Cassation File No. 63014) Federal Supreme Court Cassation Decisions, Vol. 13, pp. 359- 365).

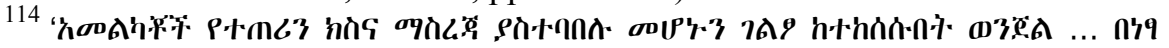

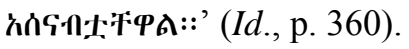


charged. ${ }^{115}$ Therefore, the Court stated that once the public prosecutor proves the existence of property in excess of the known legal income of the accused, it is up to the defendants to prove the exact source of such excess. ${ }^{116}$

The Court found that both the trial and the appellate courts failed to frame and examine these issues. It then stated the evidence that should have been required if such issues were framed. It found that the decisions of all the three courts contained fundamental error of law and remanded the case to the trial court so that these issues could be considered.

\subsubsection{Analysis}

The Cassation Bench of the Federal Supreme Court has made some important findings in the cases discussed above. In Girma T. v. Federal Ethics and AntiCorruption Commission, for example, it unequivocally stated that the burden of proof is on the public prosecutor to prove all the particulars of the offence as mentioned in the charge. Accordingly, it acquitted the defendant after finding that the prosecutor did not prove all the elements of the crime. It restated the requirement under Article 141 of the Criminal Procedure Code by noting that the trial court must engage itself in weighing of evidence and order the acquittal of the accused if the evidence of the prosecution does not prove the particulars of the offence 'sufficiently' as mentioned in the charge (and is not sufficient to warrant conviction if unrebutted). And by sufficient evidence, the Court continued, it is meant that the evidence presented must be coherent, consistent, and must have the necessary probative value to prove the charge- the closest the court has come to defining what standard of proof is to be applied in criminal proceedings. In a similar case (Awet T. v. Tigrai Public Prosecutor), the Court held that if a court fails to acquit a defendant in the face of evidence that does not warrant conviction and instead orders him to enter into his defenses that decision would amount to a 'fundamental error of law.'

In Workneh $K$. et.al., the FSC Cassation Bench gave a ruling on the controversial criminal provision of 'possession of unexplained property' looking into what was required of the defendant to discharge his burden of giving 'satisfactory explanation' of the property in his possession. The Cassation Bench implied that what was required of the accused was much higher than simply raising doubts on the case of the prosecution.

A look at these cases shows that the standard of proof employed by the various regional and federal courts from which the cases were referred to cassation is not uniform. Some stated that the guilt of the accused was

\footnotetext{
${ }^{115}$ Cr. Code, Art. 419(1).

116 Workneh K. et. al. v. SNNPR Ethics and Anti-Corruption Commission Prosecutor, supra note 113, p. 363.
} 
established by 'sufficient evidence' presented by the prosecutor while others held that the accused failed to 'effectively rebut the case of the prosecution' before passing a guilty verdict. The FSC Cassation Bench has also failed to develop a clear jurisprudence on the standard of proof that should be used in criminal cases. In Burqeso W. v. Public Prosecutor where the claimant clearly contested the standard of proof on the basis of which he was convicted, the Bench held that the guilt of the accused was 'appropriately established' by the prosecutor without, however, explaining what it meant by that. And in the case of Aregahegn M. v. Federal Ethics and Anti- Corruption Commission, the Court failed to take up standard of proof as an issue for consideration.

The Court repeatedly held that the evidence presented before the trial courts was sufficient to warrant the convictions. Differing from the findings of the trial courts, the FSC Cassation Bench in some cases held that the guilt of the accused had been sufficiently established by the prosecution and, reversing the judgment, found the defendant guilty as charged. After a similar analysis, it held the reverse in some other cases and quashed a guilty verdict. In still others it went into examining the prosecution case after which it decided that the crime charged was not proved and instead convicted the defendant under a different provision containing a crime of lesser gravity.

In a civil case (Senait Temesgen v. Etifwork Bekele), the FSC Cassation Division had made a distinction between the issue of weight of evidence as an issue of fact and consideration of whether such evidence constitutes issue of law. ${ }^{117}$ It stated that the Court has the mandate to look into the latter, but not the former adding that the question of whether the established facts constitute the legal elements of an issue at hand squarely falls under its jurisdiction. ${ }^{118}$ Such analysis and distinction seem to be missing from its jurisprudence in criminal cases.

In various criminal cases, the Court repeatedly stated that it was beyond its mandate to go into weighing of evidence. However, we find that the Cassation Bench evaluated evidence in some cases. In Oromia Region Public Prosecutor v. Eyosiyas A. et. al., for example, the court discussed the evidence presented against each defendant based on which it changed the verdict given by the lower courts. ${ }^{119}$ Contrary to the principle of presumption of innocence of the accused and the requirement that his guilt be proved beyond a reasonable doubt, the FSC

117 Senait Temesgen v. Etifwork Bekele, (Federal Supreme Court, Cassation File No. 44804) Federal Supreme Court Cassation Decisions, Vol. 11, pp. 525- 529.

${ }^{118}$ Id., p. 528; The same was held in Ethiopian Commercial Bank v. Ashebir Tadesse et al. (Federal Supreme Court, Cassation File No. 57288) Federal Supreme Court Cassation Decisions, Vol. 12, pp. 506-511.

119 Oromia Region Public Prosecutor v. Eyosiya sAberra et. al., supra note 104. 
Cassation Division required higher thresholds of evidence from the defendant than what would suffice to raise doubts on the prosecutor's case.

As mentioned earlier, the Cassation Bench has indeed raised some important points by restating the obligation of the public prosecutor to prove all elements of the crime. However, it has failed to clarify the requisite standard of proof in criminal proceedings. ${ }^{120}$

\section{Conclusion}

The standard of proof significantly affects the outcome of cases that are brought before the court. In criminal cases where the two litigants are the state (represented by the public prosecutor) and an individual, the standard of proof required of the state to prove guilt is set high reflecting the need to protect the innocent individual from wrongful conviction. The beyond a reasonable doubt standard is the construction of this high standard in common law countries. It found its way into the Ethiopian legal system through the Criminal Procedure Code which was fashioned after the common law tradition and court practice set in place by British judges in the country after the Italian occupation. The right of the accused to be presumed innocent found in the FDRE Constitution and in various international instruments which are integral parts of Ethiopia's law (by virtue of Article 9(2) of the FDRE Constitution) envisage the standard of proof beyond a reasonable doubt in criminal cases.

While this is the general framework set in place, there are a number of laws that introduce presumptions in favor of the prosecutor. Such provisions in the Criminal Code as well as other criminal legislation have the effect of shifting the evidential burden of proof to the defendant as regards some element of the crime. The trend reflected in the Criminal Justice Administration Policy and the Draft Criminal Procedure Code also seems to suggest that the types of crimes for which a presumption against the accused exist are growing. Even though some exceptions to the rule can be introduced, no yardsticks have been developed that set out conditions these exceptions must meet. In the absence of such 'limit to the limits', encroachment on the right of the individual to be presumed innocent may go unchecked as more presumptions continue to erode

${ }^{120}$ Looking at the wording in some of the cases discussed, one may argue that the Court is in favor of the 'clear and convincing evidence' standard in determining guilt of the accused; a look at other cases, however, will lead us to conclude that the Court has not taken a clear stand on the issue. Even if we were to accept the position that the Court has accepted the 'clear and sufficient evidence' formulation, since the requisite standard of proof implied in the normative framework is the higher standard of proof beyond a reasonable doubt, such stand of the Court is not in accordance with the law. 
the prosecutor's responsibility to prove all elements of the crime beyond a reasonable doubt. Apart from these exceptional provisions, even in the ordinary cases of crimes that form the bulk of what courts entertain on a daily basis, the practice in Ethiopia shows that many variations of the standard are being used by different courts. ${ }^{121}$ This has a number of implications on the criminal justice system as a whole.

The first caveat is that by deviating from the high standard of proof required in criminal cases, more innocent people may be convicted than what is considered tolerable. ${ }^{122}$ Although avoiding errors altogether would be an impossible task, the existence of a high degree of such errors greatly undermines the moral force of the criminal justice system. This in turn results in people losing faith in the criminal justice process.

Secondly, the prevalence of such divergent practice introduces a level of arbitrariness into the system. If courts employ various standards in reaching their verdict, the fate of the defendant will, at least partly, depend on which court and more particularly which judge before whom he is brought. Depending on these circumstances, therefore, a person accused of a crime may be convicted on a much lower threshold than another charged with the same crime. Such difference in treatment is a violation of the constitutional principle that all persons are equal before the law and are entitled to equal protection of the law. Article 4 of the Criminal Code holds that: "Criminal law applies to all alike... [n]o difference in treatment of criminals may be made except as provided by this Code..." Since the decision for conviction or acquittal ultimately lies with individual judges, the subjective element will inevitably affect the case. While some level of such variation may be tolerable, it must be checked to make sure that it does not amount to arbitrary outcomes in criminal cases.

Thirdly, the practice shows that enough attention is not being given to the issue of standard of proof in general. The reluctance of trial and appellate courts alike to discuss it even when it is raised as an issue for consideration by the

${ }^{121}$ There seems to be a general understanding that courts must employ a more rigorous standard of proof in criminal proceedings than in civil cases. (See Tariku C. v. Federal Ethics and Anti- Corruption Commission (Federal Supreme Court, Cassation File No. 78470) Federal Supreme Court Cassation Bench Decisions, Vol. 15, pp. 352). The question, however, is how much more rigorous it should be.

${ }^{122}$ Without doing an empirical research into the number of convictions and acquittals and such related issues, one cannot conclusively say that our system is erring on one side or the other. The existence of too many wrongful acquittals remains a possibility. However, having had the chance to observe a number of criminal proceedings entertained in federal first instance and high courts, I have noted that accused persons were convicted on evidence which, in my opinion, does not suffice to meet the rigorous standard of proof beyond a reasonable doubt. 
litigants attests to this; in some of the cases, the question of standard of proof as an issue of law was not properly distinguished from the factual issue of weighing the presented evidence. Courts mostly state that the evidence presented was 'sufficient' to warrant the guilty verdict. This statement is too vague and susceptible to discretion because it does not expressly state what is expected from courts in terms of specifying to what degree the prosecutor is required to prove guilt. The very purpose of the standard of proof is answering the question of what we mean by 'sufficient evidence.' A mere qualification of evidence as 'sufficient', as is done by various courts, only tells us that a certain standard has been met and not what that standard is.

The importance of defining and correctly applying the standard of proof in criminal cases cannot be overstated. The object and purposes of the criminal law, such as ensuring peace and security of the society and punishing the guilty, hinge on the correctness of the decisions of courts. The standard of proof, reflecting the acceptable ratio of wrongful convictions to wrongful acquittals, plays a major role on the outcome of such decisions. Pending legislative remedy to fill the gap that now exists in the Ethiopian system, the practice of courts, particularly that of the Federal Supreme Court Cassation Bench, is an important source of provisional remedy. The Ministry of Justice, as per the extensive powers given to it under the Criminal Justice Administration Policy, can also play a big role in clarifying this area of the law through the issuance of indicative practical guidelines.

The notion of proof beyond a reasonable doubt is found not only in the writings of scholars, but it is also expressed in public statements, various public prosecutor documents and some court judgments. For example, Prime Minister Hailemariam Desalegn, addressing the House of People's Representatives, stated that the Ethiopian criminal justice system made sure that individuals were convicted only when their crime has been established beyond a reasonable doubt. Public prosecutors, in passing a decision for the discontinuity of investigation, usually state that the evidence presented does not suffice to warrant the conviction of the defendant establishing guilt 'beyond sufficient doubt'. The practical aspects of these expressions and sincere allegiance to the pledges that are made toward the protection of individual rights indeed require steps to make sure that the standard of proof is set high in criminal cases and that such standard is properly understood and applied by courts. 